\title{
Potential of Actinomycetes to Inhibit the Biofilm Formation of Escherichia coli ATCC 25922
}

\author{
Meiskha Bahar ${ }^{1}$, Hany Yusmaini ${ }^{2}$, Cut Fauziah ${ }^{3}$, Fajriati Zulfa ${ }^{4}$ \\ ${ }^{1}$ Departemen Mikrobiologi, Fakultas Kedokteran, Universitas Pembangunan Nasional Veteran, Jl. R.S Fatmawati No. \\ 1, Jakarta Selatan 12450, Indonesia \\ ${ }^{2}$ Departemen Farmakologi, Fakultas Kedokteran, Universitas Pembangunan Nasional Veteran, Jl. R.S Fatmawati No. \\ 1, Jakarta Selatan 12450, Indonesia \\ ${ }^{3}$ Departemen Biologi, Fakultas Kedokteran, Universitas Pembangunan Nasional Veteran, Jl. R.S Fatmawati No. \\ 1, Jakarta Selatan 12450, Indonesia \\ ${ }^{4}$ Departemen Parasitologi, Fakultas Kedokteran, Universitas Pembangunan Nasional Veteran, Jl. R.S Fatmawati No. \\ 1, Jakarta Selatan 12450, Indonesia \\ *Corresponding author: meiskha27@gmail.com
}

\section{ABSTRACT}

Actinomycetes are soil microbes that can synthesize secondary metabolites such as antimicrobial, antifungal, and antitumor. These microbes are classified as Gram positive bacteria. They can grow very well under any conditions from fertile soils to under alkaline dry conditions. Several types of bacteria can form biofilms, which play a role in the process of infection, resistance and chronic diseases that are very difficult to treat with antimicrobial therapy. This study aims to determine the activity of Actinomycetes isolates antibiofilm on the formation of E. coli biofilms in vitro. This research was a true experimental by taking isolates from Kebun Raya Bogor with 10 points in the west area, using a 96 wells microtiter plate. Biofilm measurements on a microplate reader and obtain quantitative data in the form of Optical Density at a $595 \mathrm{~nm}$ wavelength. The results showed that isolate no 6 had the largest percentage of $93.02 \%$ and $83.75 \%$ with an average percentage of $88.35 \%$. ( $\mathrm{p}<0.05$ ). It can be concluded that Actinomycetes isolates from Kebun Raya Bogor have the potential to produce antibiofilms against $E$. coli by interfering with the quorum sensing system.

Keywords : Actinomycetes, antibiofilm, Escherichia coli

\section{INTRODUCTION}

Actinomycetes are a group of microorganisms that are the most widely distributed microorganisms in nature, especially in land and sea. These microbes are classified as Gram positive. They can grow very well under any conditions, even under conditions of dry alkali, Actinomycetes Habitat is widely available in soils that generally contain organic matter. Actinomycetes are soil microbes that are able to synthesize secondary metabolites such as antimicrobial, antifungal, and antitumor (1).

Recent advances have been made in the discovery of antibiotics from Actinomycetes by 
using high-tech fermentation, isolation of Actinomycetes from the sea, mining genomes for cryptic pathways, and combined biosynthesis to produce new secondary metabolites associated with existing pharmaako-phore. (2).

Several studies that have succeeded in isolating the presence of Actinomycetes microbes in both land and sea, include research from Ambarwati, 2009 which succeeded in isolating Actinomycetes from rice fields, Adriani (2013) who succeeded in isolating Actinomycetes from Soil Samples in Cattle Farms in Galesong District, and the ability of isolates Actinomycetes as proteolytic and amylolytic bacteria E.coli (Bahar, 2017) are the main reasons for the development of research and methods to find out other benefits that can be obtained from the use of Actinomycetes as antimicrobials. $(3,4)$.

Escherichia coli is a microorganism also known as normal flora where the life is found in the human digestive tract and in infants who are a few hours old. Normally, E. coli and humans can live in harmony together in healthy and mutually beneficial conditions for some time. Normally normal E. coli strains rarely cause disease except in patients with immunocompromised conditions or the presence of a blockage in the gastrointestinal tract, such as peritonitis. This normal E. coli is in the mucous layer in the human large intestine(5).

In a healthy human body, E. coli plays a role in the synthesis of vitamin $\mathrm{K}$, conversion of bile pigments, bile acids and absorption of food substances. In addition, E. coli also acts as a defense mechanism against infection, because it produces colicin which protects the digestive tract from pathogenic bacteria (6).

However, there are some E. coli that obtain specific virulence properties so that they are able to survive and adapt to new conditions well and this allows them to cause a broad spectrum of diseases. These virulence organelles are often encoded in genetic elements that can be converted into various strains to produce new combinations of virulence factors, or to genetic material that may have been immobile, but now have evolved to be 'locked' into the genome. Only the right combination of virulence factors can survive to be specific "pathotypes" of E. coli that can cause disease in healthy individuals(5).

The process of biofilm formation in microorganisms can increase tolerance to antimicrobials and disinfectants, so biofilms play a major role in the occurrence of resistance and chronic disease. Biofilms contribute up to $60 \%$ in conditions of human infection and are very difficult to treat with antimicrobial therapy. In vitro susceptibility testing has shown an increase in biofilm cell resistance to the prevention of E.coli bacteria (7) .

Increased incidence of resistance to antibiotic use has led to many researchers conducting research to obtain antimicrobials that are more able to minimize the incidence of resistance, one of which is antimicrobial research derived from microorganisms. From the land that is spread in Indonesia there are millions of antimicrobialproducing microbes. Currently the source that is being developed because many produce antimicrobials are microbes from the class Actinomycetes (especially the genus Streptomyces) which produce compounds or enzymes that are useful in antimicrobials. Microbial groups can produce compounds that can inhibit the growth of pathogenic bacteria. There are several studies that have proven that Actinomycetes contain compounds or enzymes that are useful as antimicrobials (2). Based on the results of Actinomycetes isolates have potential as antimicrobials, making us then conduct antibiofilm tests with the aim to find out whether Actinomycetes can inhibit the formation of biofilms from E.coli. 


\section{MATERIALS AND METHOD}

This type of research is a true experimental study with a posttest only control group design. The sample used in this study was Actinomycetes which was isolated from the soil of Kebun Raya Bogor.

This study is in accordance with the results of the Frederer formula, microtiter plate wells used as samples, 24 wells in 12 groups to inhibit the formation of E.coli biofilms with the number of two repetitions per group. Inhibition of the formation of E. coli biofilms consisted of test groups (Isolates 1 to isolate 10) given $100 \mu \mathrm{L}$ liquid TSB media, $50 \mu \mathrm{L}$ E.coli bacterial suspension and $50 \mu \mathrm{L}$ Actinomycetes bacterial suspension, mixed and inserted into each microplate well, control group negative, the well was only given $100 \mu \mathrm{L}$ TSB liquid media and $100 \mu \mathrm{L}$ suspension of E. coli. The positive control group, the solvent control, $\mathrm{NaCl}$, and the media control group contained $200 \mu \mathrm{L}$ TSB media.

\section{a. Sterilization of tools and materials}

All equipment to be used is washed, dried, wrapped in paper and sterilized in an oven at $200{ }^{\circ} \mathrm{C}$ for $1-2$ hours. The material to be used for microbiological tests is sterilized by autoclaving at $121^{\circ} \mathrm{C}$ for $15-20$ minutes.

\section{b. Soil Sampling}

Samples are taken at 10 different points to get maximum results by taking into account the conditions of the temperature and $\mathrm{pH}$ of the environment and the type of location of the soil where the sample was taken. Soil is taken near the root of the tree with a depth of 10-15 $\mathrm{cm}$ from the soil surface. The soil taken is dark topsoil, temperature $25-37^{\circ} \mathrm{C}$, optimum $\mathrm{pH} 7-8$, the weather is not hot nor cold with clay soil texture.

After fulfilling these criteria the soil sample is put into 10 sterile lid tubes. The tube containing the research sample was then put into a coolbox and then taken to the Microbiology Laboratory of FKUPN "Veteran" Jakarta for observation

\section{c. Bacteria Stock Preparation}

E.coli ATCC 25922 derived from pure culture of McConkey Agar (MCA) from the Microbiology Laboratory of the UPN "Veteran" Medical Faculty in Jakarta, then etched on NA agar media, then incubated for 18-24 hours at $37^{\circ} \mathrm{C}$ and stored in the refrigerator

\section{Escherichia coli ATCC 25922 culture}

E. coli was inoculated by the streak method on Eosin Metyl Blue Agar (EMB) media, and incubated for 24 hours at $37^{\circ} \mathrm{C}$. The EMB media consisted of $36 \mathrm{~g}$ of Eosin Metyl Blue Agar and $4.5 \mathrm{~g}$ of $30 \%$ agar in $1 \mathrm{~L}$ of distilled water ((Triana, 2018)

\section{Actinomycetes isolate culture}

In this study the material used for isolation of Actinomycetes is a soil sample from the kebun raya Bogor. Taken with a depth of 10$15 \mathrm{~cm}$ from the ground surface. The sample is put into a sterile bottle and stored in a coolbox, then taken to the laboratory for use in research. The step of making Actinomycetes isolates

\section{d. Actinomycetes Identification}

Macroscopic identification was carried out after incubation with an incubator for 3 weeks to see the growth of Actinomycetes on SCA media. Positive results for Actinomycetes will produce a yellowishwhite colony, a colony that looks rough and powdery, chapping like a root. After macroscopy identification is continued with Gram staining.

Gram staining begins with cleaning the glass object first with a clean cloth or tissue. Glass objects are passed over the Bunsen 
burner to remove fat and allow it to cool. Draw a circle with a marker pencil $1.5-2 \mathrm{~cm}$ in diameter at the "bottom" of the glass object. Put $\mathrm{NaCl}$ by using a round nose on top of the glass object that has been given a circle underneath it with pencil markers. Take some culture cuffs, spread them and mix on top of the glass object which has been given a circle on the bottom with a pencil marker by rotating (coiling). The preparation is left to dry in the air. Dry preparations are passed over the Bunsen burner 3 times (Fixation), dripping purple carbolic crystals and leave for 5 minutes. Tilt the glass object, then wash with running water until the water flowing over the glass object is clear.

Drop lugol liquid, leave for 60 seconds, then wash with running water. Give alcohol to stand for 30 seconds Wash with running water and cover with dripping water safranin left for 1 minute, wash with running water until there is no dye in the preparation and dry with filter paper.

The preparations are ready to be observed under a microscope and identify the results of the examination, in the form of fine (sometimes) filamentous, sometimes singlebranched, purple-colored structures with Gram-positive properties.

\section{e. Antibiofilm Assay}

$200 \mu \mathrm{L}$ of Actinomycetes suspension was put into a microplate, closed and incubated for 60 minutes. After incubation, the suspension is removed and then $100 \mu \mathrm{L}$ of LB media and $100 \mu \mathrm{L}$ of E. coli are added. The negative control was $200 \mu \mathrm{L}$ bacterial suspension and the positive control was Ceftriaxone. The microplate was closed and incubated for 48 hours at $37^{\circ} \mathrm{C}$. After the incubation period is complete, the contents of the microplate are discarded, the microplate is washed with water and dried. The microplate was washed using $200 \mu \mathrm{L} \mathrm{96 \%}$ ethanol and incubated for 15 minutes at room temperature. The microplate was stained using $200 \mu \mathrm{L} 1 \%$ violet crystal, incubated for 15 minutes at room temperature, the violet crystal was removed, the microplate was washed with water and dried. The microplate was dripped with $200 \mathrm{~mL}$ of $33 \%$ acetic acid and incubated for 15 minutes at room temperature. Optical density (DO) was measured using a microplate reader at 595 nm. Optical density was measured using a microplate reader at $595 \mathrm{~nm}$ (8). The test was carried out triplo and the percentage of biofilm inhibition was calculated using the following formula (9):

$$
\begin{aligned}
& \% \text { Inhibition }=\frac{(\mathrm{C}-\mathrm{B})-(\mathrm{T}-\mathrm{B})}{(\mathrm{C}-\mathrm{B})} \times 100 \% \\
& \text { information : } \\
& \mathrm{C}=\text { Optical Density (OD) } 595 \mathrm{~nm} \text { control } \\
& \text { media, } \\
& \mathrm{B}=\mathrm{OD}_{595} \text { negative controls, } \\
& \mathrm{T}=\mathrm{OD}_{595} \text { treated wells. }
\end{aligned}
$$

\section{RESULT AND DISCUSSION}

\section{Result}

The research began from the stage of taking and collecting samples taken from the soil of the Kebun Raya Bogor by taking into account the condition of the soil, temperature and $\mathrm{pH}$ measured 3 days before, the location of the land close to the plant root system. Then soil samples are taken from ten points with a distance between points of approximately 250 - 300 meters.

From all points, samples were collected which were then microscopic and macroscopic identification. Microscopic results through Gram Staining found positive results for Actinomycetes with identification in the form of: Form of smooth bacilli (length / filament), there is a single arrangement and there is a chain, purplecolored,Gram positive (fig 1).

Macroscopic test results in the form of observations of growth of Actinomycetes isolates 
on Starch Casein Agar media, positive results showed colonies covered by air mycelium and had hyphae surrounded by hydrophobic sheaths from the surface of the colony to free air.
Actinomycetes have different colony colors due to differences in the pigment content of each constituent cell (fig 2).

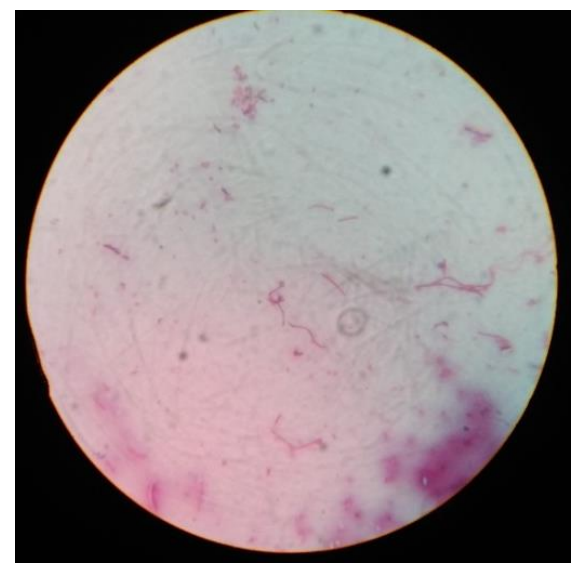

Figure 1. Gram staining of Actinomycetes isolate under 10x100 magnification
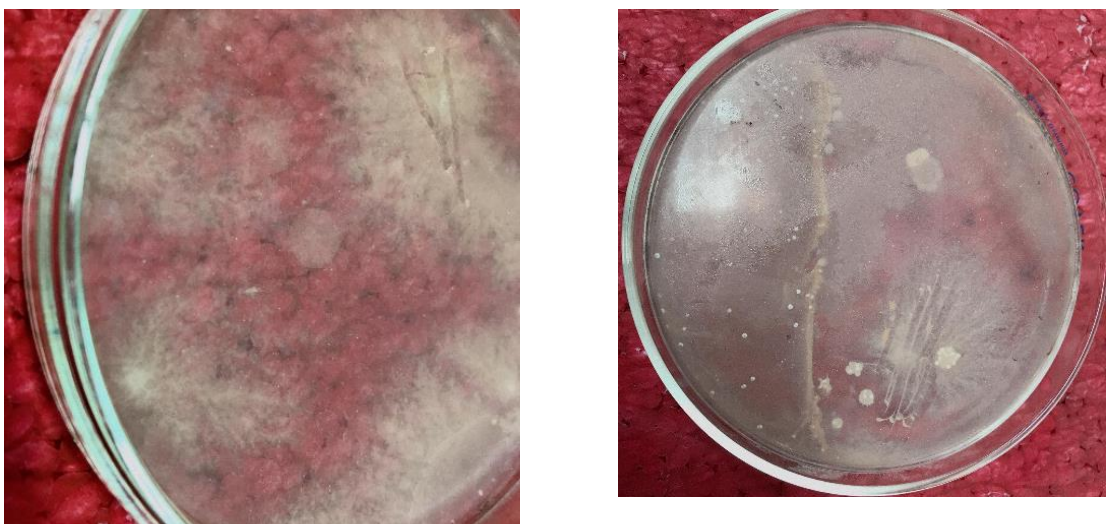

Figure 2. Growth of Actinomycetes isolates on Starch Casein Agar media (incubation 3 weeks)

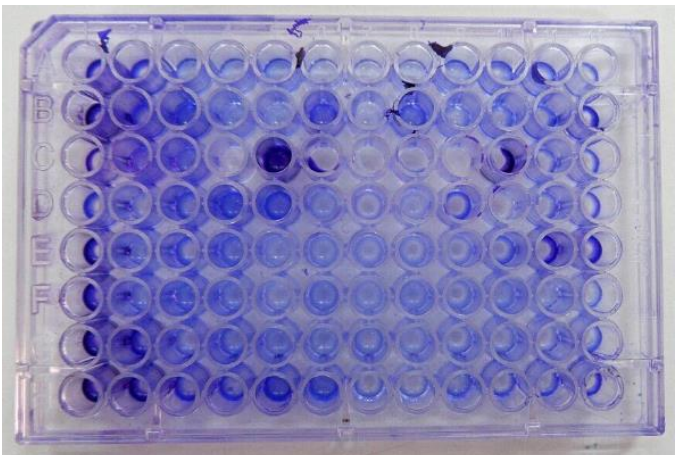

A

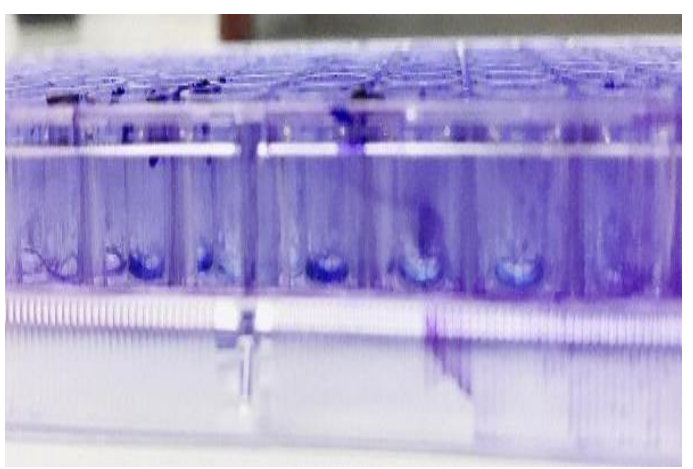

B

Figure 3 (A) A purple well indicates biofilm; (B) E. coli biofilms are formed at the bottom of the well, this is shown from the deposition of violet crystal color at the bottom of the well. 


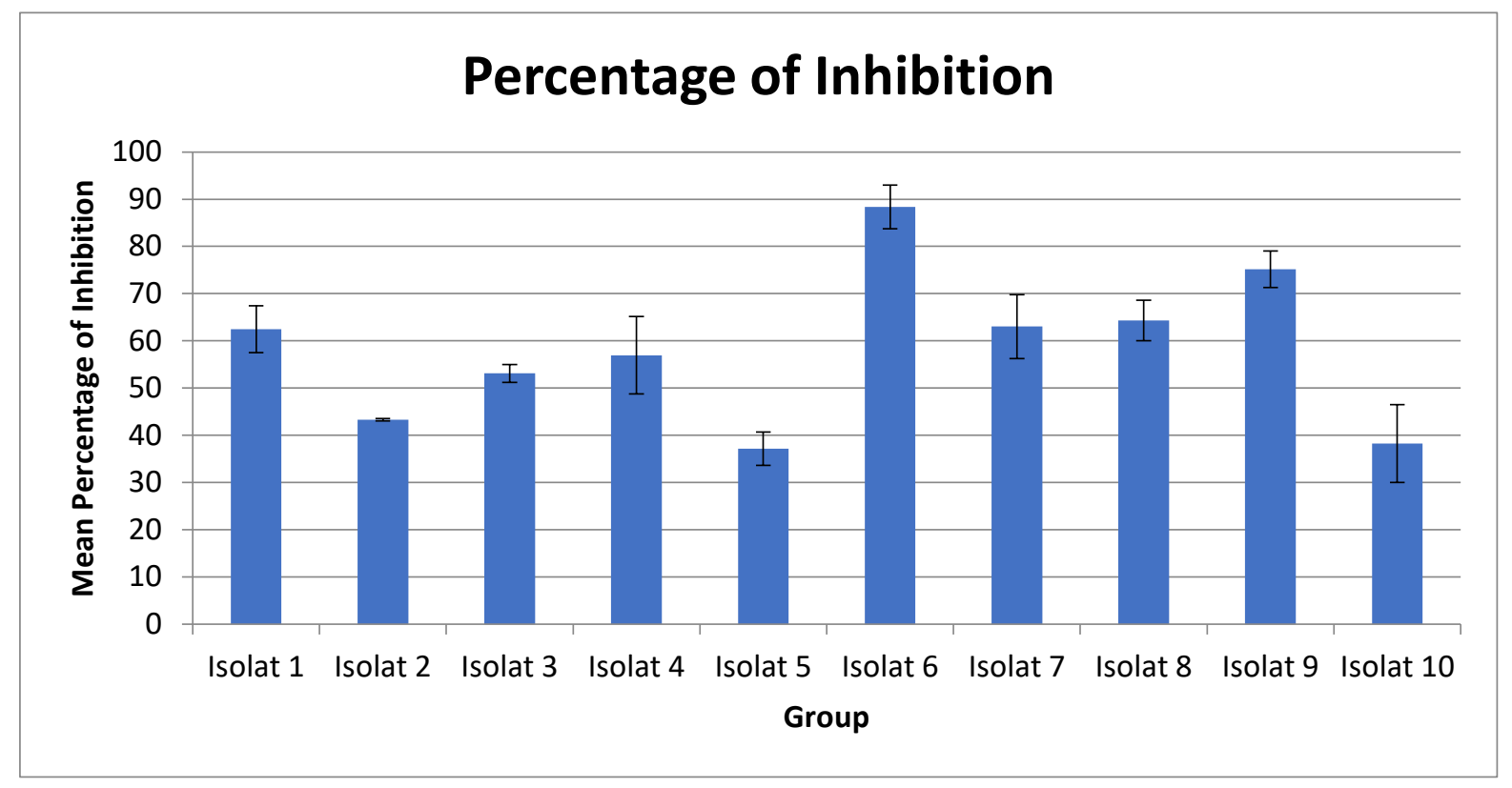

Figure 4. Percentage diagram of Actinomycetes isolate inhibition

\section{Evaluation of Biofilm Formation}

Biofilm formation from E.coli can be observed from the formation of purple color in the microplate wells, if the microplate remains purplish-blue, then biofilms have formed in the microplate wells. Evaluation of the formation of biofilm E. coli on a 96 wells U-shape bottom microplate.

The results of this study indicate that ten isolates of Actinomycetes taken from Kebun Raya Bogor turned out to have potential as microbes that are as antibiofilms from Escherichia coli. this can be seen from table 1 which shows the percentage of biofilm inhibition. The highest percentage of inhibition was found in isolate 6 with a percentage of $93.02 \%$ and $83.75 \%$ with an average percentage of $88.35 \%$.

Formation and evaluation of biofilm inhibition were carried out by the microtiter plate method. The formation of biofilms is characterized by a purple well, as a representative of the formation of biofilms formed by E.coli. If observed from the side of the purple color formed at the bottom of the well it is caused because E.coli is classified into motile bacteria (having flagellum) and actively moving, in contrast to non-motile bacteria that show purple in the entire wall of the well (10).

E. coli is a facultative anaerobic bacteria, so that on microdilution testing, bacteria gather in the well wall. Staining with $0.1 \%$ violet crystal aims to dye bacterial biofilms composed of cell layers and exopolysaccharides (EPS). Violet crystals will bind negative charges on the surface of molecules and polysaccharides on EPS (11) .

In Gram-negative bacteria, the quorum sensing system uses the Acyl Homoserine Lactone (AHL) signal molecule, so some ways that can interfere with the quorum sensing system are by inhibiting the formation of AHL signals, inhibiting the spread of AHL signals, and inhibiting the reception of AHL signals (12).

Research results from Leetanasaksakul, 2018 show that most of the substances released from marine actinomycetes inhibit the formation of $E$. coli and $S$. aureus biofilms but do not cause lethal effects. Some strains that carry out protease activity are thought to inhibit the formation of biofilms by proteolytic action. Cellular proteins possessed by Gram negative bacteria play a role in biofilm formation and participate in structural and quorum sensing functions (8). The 
proteolytic activity of Actinomycetes is considered to work as a potential antibiofilm by interfering with the quorum sensing system by inhibiting the formation of AHL signals from E.coli extracellular protein so that E.coli cannot produce biofilms to the maximum.

\section{CONCLUSION}

This study signified that Actinomycetes obtained from Kebun Raya Bogor are good sources of promising anti-biofilm producers. This is supported by the biological resources and the condition of Kebun Raya Bogor which provide potential substances. From this study showed that Isolate no 6 has the largest percentage in inhibiting the biofilm of $E$. coli in vitro with an average percentage of $88.35 \%$.

\section{REFERENCES}

[1] Mustafa O, A. UT, Cem A. Antibacterial activity of some actinomycetes isolated from farming soils of Turkey. African $\mathbf{J}$ Biotechnol [Internet]. 2004 Sep 30 [cited 2019 Jan 10];3(9):441-6. Available from: http://academicjournals.org/journal/AJB/art icle-abstract/CE19B8732789

[2] Ambarwati T dan Azizah Gama. ISOLASI ACTINOMYCETES DARI TANAH SAWAH SEBAGAI PENGHASIL ANTIBIOTIK ACTINOMYCETES ISOLATION FROM LAND RICE FIELD AS ANTIBIOTIC PRODUCER [Internet]. surakarta; 2009 [cited 2019 Jan 10]. Available from: https://publikasiilmiah.ums.ac.id/bitstream/ handle/11617/437/1.

AMBARWATI.pdf?sequence $=1 \&$ isAllowe $\mathrm{d}=\mathrm{y}$

[3] Hasyim A, Tulak YF. Isolasi dan Karakterisasi Actinomycetes Sebagai Penghasil Antibiotik Dari Sampel Tanah Pada Peternakan Sapi di Kecamatan Galesong Kabupaten Takalar. Biog J Ilm Biol [Internet]. 2013 [cited 2019 Jan
10];1(2):97-100. Available from: http://journal.uinalauddin.ac.id/index.php/biogenesis/article/ view/454/431

[4] Bahar M, Zulfa F. EFEKTIVITAS ANTIBAKTERI ISOLAT Actinomycetes TERHADAP AKTIVITAS

PROTEOLITIK DAN AMILOLITIK Escherichia coli ATCC 25922 Bulan ke 4 dari rencana 4 bulan Tim Peneliti dr . Fajriati Zulfa Mbiomed FAKULTAS KEDOKTERAN UNIVERSITAS PEMBANGUNAN NASIONAL “ VETERAN. 2017. 1-51 p.

[5] dr Maria Ulfa M. PATOGENESIS ESCHERICHIA COLI | Master of Hospital Management [Internet]. [cited 2019 Jan 9]. Available from: http://mmr.umy.ac.id/en/patogenesisescherichia-coli/

[6] Cornelissen, Cynthia Nau; Fisher B d.; harvey richard A. Lippincott's Illustrated Review Mikrobiologi Jilid 2 - Toko Buku Karisma. ketiga, jilid dua. meiskha bahar, editor. jakarta: binarupa aksara; 2008.

[7] Tajbakhsh E, Ahmadi P, AbedpourDehkordi E, Arbab-Soleimani N, Khamesipour F. Biofilm formation, antimicrobial susceptibility, serogroups and virulence genes of uropathogenic E. coli isolated from clinical samples in Iran. Antimicrob Resist Infect Control. 2016;

[8] Leetanasaksakul K, Thamchaipenet A. Potential anti-biofilm producing marine actinomycetes isolated from sea sediments in Thailand. Agric Nat Resour [Internet]. 2018;52(3):228-33. Available from: https://doi.org/10.1016/j.anres.2018.09.003

[9] Triana E. AKTIVITAS ANTIBIOFILM BAKTERI Escherichia coli OLEH BAKTERIOFAG SECARA IN VITRO. Ber Biol [Internet]. 2018 Jul 13 [cited 2019 Jan 10];17(1):77. Available from: http://ejournal.biologi.lipi.go.id/index.php/berita_b iologi/article/view/3234

[10] O'Toole GA. Microtiter dish Biofilm formation assay. J Vis Exp. 2010;(47).

[11] Putri S, Sari W, Rahmapuspita F, Iriyani N, Utami S, Pratiwi T, et al. Penelusuran Potensi Kapulaga , Temu Putri dan Senggugu sebagai Penghambat 
Pembentukan Biofilm ( Screening of Kapulaga , Temu putri and Senggugu Potencies for Inhibition of Biofilm Formation ). 2014;12(1):17-24.

[12] AINI N, SETYAWAN AD. Bioactive compound that inhabit quorum sensing system in gram negative bacteria. Biofarmasi $J$ Nat Prod Biochem. 2006;4(1):34-40. 